\title{
Numerical Taxonomy and Laboratory Identification of Bacterionema matruchotii, Rothia dentocariosa, Actinomyces naeslundii, Actinomyces viscosus, and Some Related Bacteria
}

\author{
By K. HOLMBERG AND H. O. HALLANDER \\ Department of Clinical Bacteriology, Central Hospital \\ S-72I 89 Västerås, Sweden
}

(Received 28 July 1972; revised 28 November 1972)

\section{S U M MAR Y}

A collection of Gram-positive filamentous and/or diphtheroidal organisms was classified by means of numerical phenetic methods. The collection comprised 76 new isolates from dental plaques, upper respiratory tracts and urinary tracts, and 47 reference strains. The organisms were characterized according to 77 different features. The data were subjected to computer analysis in which the similarity coefficient $\left(\mathrm{S}_{3}\right)$ and the simple matching coefficient $\left(\mathrm{S}_{\mathrm{S}}\right)$ were calculated and the results of a single-linkage cluster-analysis technique and a minimum spanning tree technique were compared. The two cluster-analysis techniques gave almost identical results, but with the simple matching coefficient a few strains were grouped together on the basis of negative correlations.

Fixed levels of agreement were chosen to define genera and species. With the matching coefficient five major clusters were recognized at a similarity level of $87.5 \%$. These clusters correspond to the genera Corynebacterium, Bacterionema (Leptotrichia), Rothia, Actinomyces and Nocardia. The genera Corynebacterium, Actinomyces and Nocardia each contained a number of species. At an agreement level of $90^{\circ}$ the clusters of Bacterionema and Rothia were identical to those at $87.5 \%$ which means that these genera each contain one species. The reference strains labelled Actinomyces naeslundii and A. viscosus agreed on the $92.5 \%$ level which means that they form a single species. A 'calculated median organism' for each of these taxo-species is described. A serological grouping by immunofluorescence of all the organisms studied, by means of type-specific antisera to Bacterionema matruchotii, Rothia dentocariosa, A. naeslundii and A. viscosus, corresponded to the numerical grouping.

Characters, both constant and discriminative, were selected to form a set of tests useful for clinical laboratory identification of this group of bacteria.

\section{INTRODUCTION}

Bacterionema matruchotii, Rothia dentocariosa, Actinomyces naeslundii and $A$. viscosus are Gram-positive pleomorphic organisms recoverable from the human oral cavity and other human habitats (Onisi, I949; Thompson \& Lovestedt, I95I ; Roth, I957; Bowen, I959; Davis \& Baird-Parker, I959; Davis \& Freer, 1960; Gilmour, Howell \& Bibby, I96r $a$; Howell, Stephan \& Paul, 1962; Rasmussen, Gibbons \& Socransky, 1966; Gerencser \& Slack, 1967; Snyder, Bullock \& Parker, 1967; Brown, Georg \& Waters, I969; Slack, Landfried \& Gerencser, 1970). These organisms have lately become a focus of attention because of their possible pathogenicity in periodontal diseases (Roth \& Flanagan, 1969; Socransky, Hubersak \& Propas, 1970; Jordan, Keyes \& Bellack, 1972) and in other suppurative and granulomatous lesions of man (Brown et al. 1969; Coleman, Georg \& Rozzell, 1969). 
These organisms are closely related morphologically and physiologically. They are also related to other Gram-positive filamentous and/or diphtheroid organisms classified in the families Actinomycetaceae, Streptomycetaceae and Mycobacteriaceae of the order Actinomycetales and to the family Corynebacteriaceae of the order Eubacteriales. However, the taxonomy of this group of organisms is still uncertain.

The taxonomic position of Rothia dentocariosa and Actinomyces viscosus has recently been clarified. For $R$. dentocariosa, previously named $A$. dentocariosa, Nocardia dentocariosa and $N$. salivae, a new genus Rothia of the family Actinomycetaceae has been formed (Georg \& Brown, 1967). The animal strain Odontomyces viscosus (Howell, Jordan, Georg \& Pine, I965) was named A. viscosus after the generic description of Actinomyces had been broadened to include catalase-positive organisms (Georg, Pine \& Gerencser, 1969). The human type of A. viscosus probably corresponds to the organisms known previously as $A$. discofoliatus (Grüter, 1932).

This classification, based on classical morphological and biochemical criteria, has been supplemented to some extent by serological (e.g. Gerencser \& Slack, 1969; Slack \& Gerencser, 1970) and DNA studies (Hammond, 1970 b).

Because of their uncertain taxonomy, and the fact that many of these organisms are rather fastidious and difficult to cultivate, they have often, for convenience, been referred to as diphtheroids without further specification. However, the need for a practical diagnostic scheme to identify these bacteria became evident when interference between Gram-positive micro-organisms indigenous to dental plaques was studied (Holmberg \& Hallander, 1972).

By using a phenetic approach and a broad range of tests, the method of numerical taxonomy (Sokal \& Sneath, 1963; Lockhart \& Liston, 1970) was used to classify these organisms on the basis of overall similarity. Previously a similar study of the general similarity of certain actinomycetes mainly of oral origin has been presented (Melville, 1965). The present account combines a numerical analysis of a range of characters of Gram-positive pleomorphic organisms from various human sources with an immunofluorescence analysis. Another aim was to select discriminative characters suitable in diagnostic keys for identification of Bacterionema matruchotii, Rothia dentocariosa, Actinomyces naeslundii and A. viscosus in the clinical laboratory.

\section{METHODS}

Organisms. Gram-positive, filamentous and/or diphtheroid bacteria (76) representing various morphological groups were arbitrarily selected from saliva, dental plaques, upper respiratory and urinary tracts. Specimens from the oral cavity were cultured aerobically or anaerobically on NAYS-agar (Davis \& Freer, 1960) modified by addition of polymyxin sulphate $(25 \mathrm{IE} / \mathrm{ml})$. The isolates from the upper respiratory and urinary tracts were recovered in aerobic cultures on blood-agar from specimens submitted for routine bacteriological examination.

Reference strains (47) of Rothia dentocariosa, Bacterionema matruchotii (Leptotrichia dentium), Actinomyces spp., Leptotrichia buccalis, Corynebacterium spp., Lactobacillus spp., Nocardia spp., Mycobacterium spp. and Streptomyces azureus were obtained from the culture collections, listed in Table I. All bacteria were maintained on NAYS-agar or Tryptic Soy Broth (Difco) and also stored lyophilized.

Methods of testing. All bacteria were subjected to a series of morphological, physiological and biochemical tests (Table 3) which included the recommendations of the Subgroup of Taxonomy of Microaerophilic Actinomycetes (Slack, I968). Each isolate was tested three times, and when different results were obtained, the results shown twice were taken. 


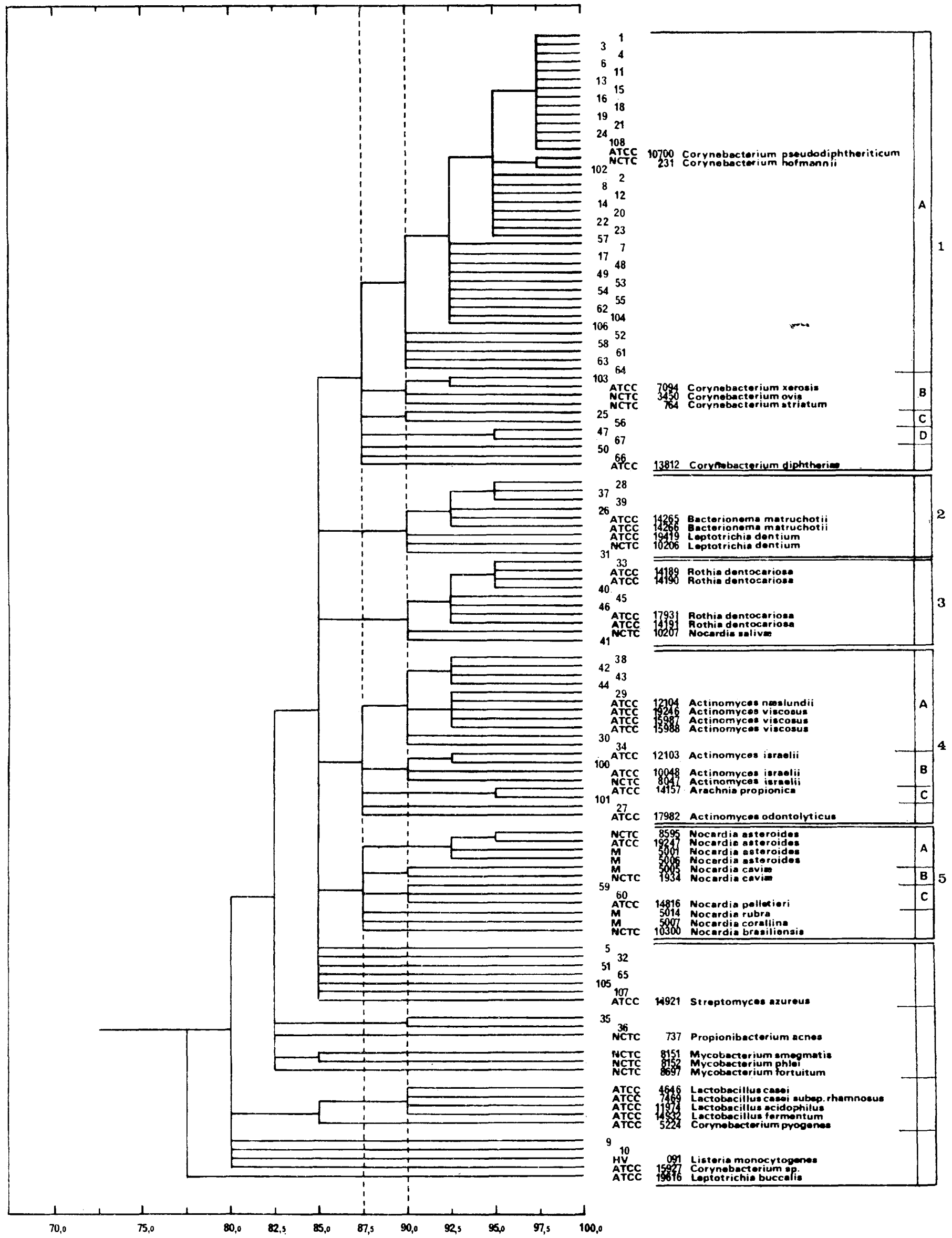

Fig. I. Dendrogram of relationships within and between clusters formed, negative matches included. 


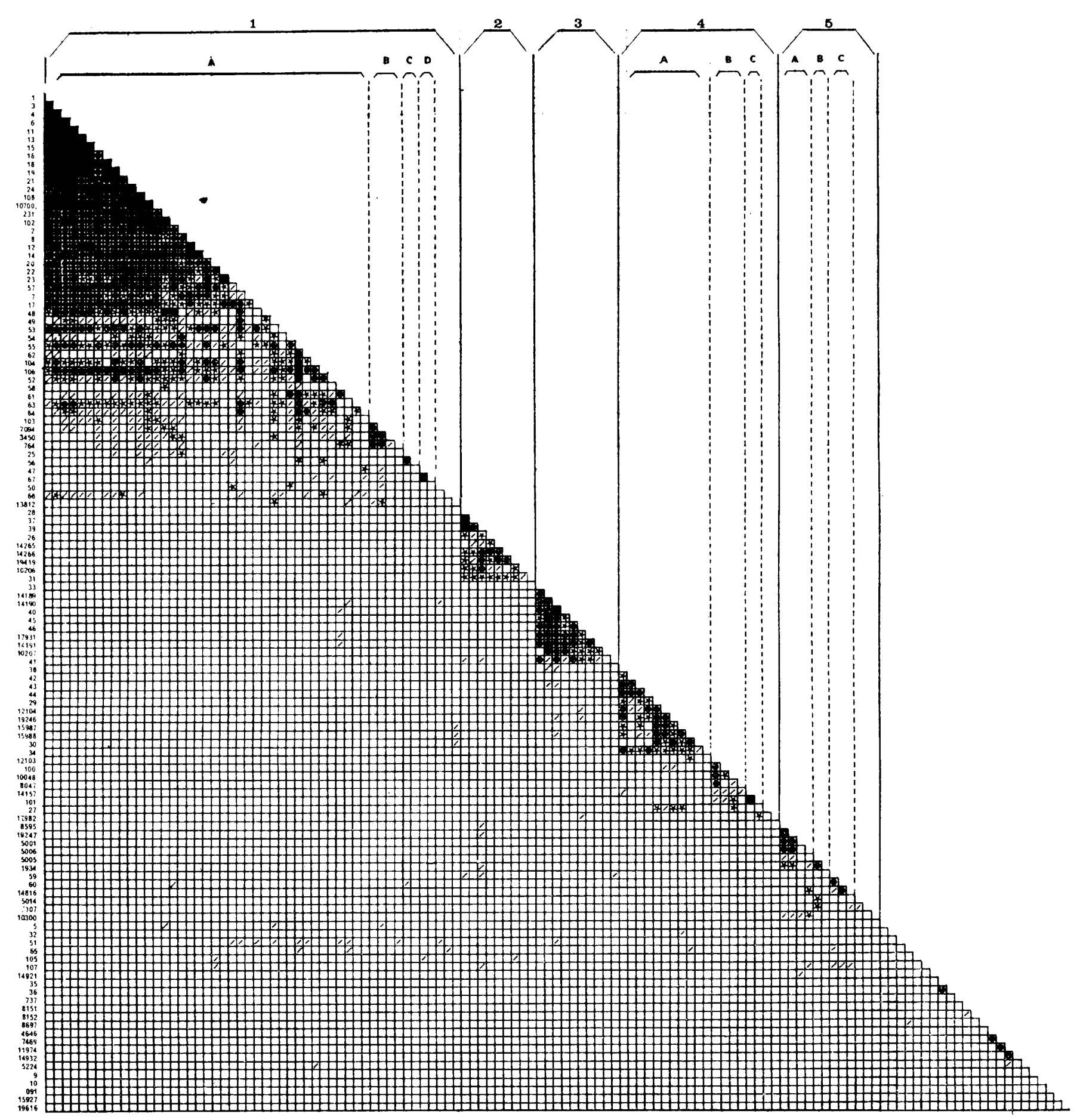

100.0-9.95\%

90.0-8.5\%

\87.9-85.\%

Fig. 2. Matching matrix of the organisms tested, based on 77 characters. 
Table I. List of organisms

Organisms Source/no.

Corynebacterium pseudodiphtheriticum (C. hofmannii) АTCC 10700 C. hofmannii

NCTC $23 \mathrm{I}$

C. xerosis

C. ovis

C. striatum

C. diphtheriae

$C$. pyogenes

Corynebacterium sp.

ATCC 7094

NCTC 3450

NCTC 764

ATCC I38I 2

ATCC 5224

Propionibacterium acnes (Corynebacterium acnes)

ATCC I 5927

Listeria monocytogenes (serotype I)

NCTC 737

Lactobacillus casei

* 09I

L. casei subsp. rhamnosus

ATCC 4646

L. acidophilus

L. fermentum

Bacterionema matruchotii

B. matruchotii

ATCC 7469

ATCC I 1974

ATCC I 4932

Leptotrichia dentium

ATCC 14265

ATCC I 4266

L. dentium

L. buccalis

Rothia dentocariosa

ATCC 19419

NCTC 10206

ATCC 196I 6

$R$. dentocariosa

$R$. dentocariosa

ATCC 1793 I

$R$. dentocariosa

ATCC 14189

ATCC 14190

Nocardia salivae

ATCC I4I9I

$N$. asteriodes

NCTC 10207

$N$. asteriodes

Malmö 500I

N. asteriodes

Malmö 5006

$N$. asteriodes

ATCC 19247

$N$. caviae

$N$. caviae

NCTC 8595

NCTC 1934

N. rubra

$N$. brasiliensis

$N$. pelletieri

MaImö 5005

Malmö 50I4

NCTC 10300

$N$. corallina

ATCC 14816

Actinomyces viscosus

Malmö 5007

A. viscosus

A. viscosus

A. naeslundii

ATCC 19246

ATCC 15987

ATCC 15988

ATCC 12104

A. odontolyticus

ATCC 17982

A. israelii

$A$. israelii

A. israelii

NCTC 8047

ATCC 10048

Arachnia propionica

ATCC I4I 57

Mycobacterium smegmatis

NCTC 8I 52

NCTC 8I 5 I

M. fortuitum

NCTC 8697

Streptomyces azureus

NCTC I 492 I

26 'diphtheroid' isolates from the oral cavity

25 'diphtheroid' isolates from the upper respiratory tracts

25 'diphtheroid' isolates from the urinary tracts

ATCC, The American Type Culture Collection, U.S.A.; NCTC, The National Collection of Type Cultures, London; Malmö, I. Juhlin, Department of Clinical Bacteriology, University of Lund, Malmö, Sweden.

* Isolate from blood. 
Bacteria were grown for 48 to $72 \mathrm{~h}$ on NAYS-agar and suspended in phosphate-buffered saline $(0.05 \mathrm{M}, \mathrm{pH} 7.2)$ to a density of approx. 0.20 at $540 \mu \mathrm{m}$ (Coleman junior spectrophotometer, Coleman Instrument Inc., Maywood, Illinois, U.S.A.). The different media were inoculated with two to three drops of the suspension and incubated at $37^{\circ} \mathrm{C}$ aerobically or anaerobically in jars with Gas-Pac (BBL) and inspected after 2, 5 and 7 days.

Morphology and staining properties were examined on smears, Gram-stained and methylene blue stained according to the Manual for the Identification of Medical Bacteria (Cowan \& Steel, 1965), from 7 day NAYS-agar cultures. Motility was inferred by observing the spreading growth into semisolid nutrient agar $(0 . \mathrm{I} \%, \mathrm{w} / \mathrm{v})$. Aerobic, with and without $\mathrm{CO}_{2}$, and anaerobic growth as well as colony characters and pigmentation were observed after incubation for 7 days on NAYS-agar. Similarly, potassium-tellurite inhibition, tested on NAYS-agar containing 0.07 and $0.3 \%(\mathrm{w} / \mathrm{v})$ of the substance, and growth on Rogosa-SLagar (Difco) were examined after 7 days. Growth with ammonium ions as sole source of nitrogen was recorded after 7 days on the basal medium described by Tsukamura (I967) and containing $2.64 \mathrm{mg}$ ammonium sulphate $/ \mathrm{ml}$.

Catalase activity, oxidase activity (Kovacs' method), indole production ( $\mathrm{I} \%, \mathrm{w} / \mathrm{v}$, tryptone water; detected by Kovacs' reagent), methyl red and Voges-Proskauer tests (Barritt's modification) were tested according to Cowan \& Steel (1966). For testing urease activity organisms were grown in the medium devised by Christensen (1946). Tests for reduction of nitrate and nitrite were carried out by incubating the bacteria in Tryptic nitrate medium (Difco, Detroit, Michigan, U.S.A.) and Tryptic Soy Broth (Difco) containing $0.01 \%$ (w/v) potassium nitrite for 5 days. Nitrite was demonstrated according to the Methods in Microbiology (Holding \& Collee, I97I). Aesculin hydrolysis was studied with tubes containing Infusion broth (Difco) with $0.1 \%(\mathrm{w} / \mathrm{v})$ agar and $0.1 \%(\mathrm{w} / \mathrm{v})$ aesculin. Hydrolysis was demonstrated by adding drops of a $\mathrm{I} \cdot 0 \%(\mathrm{w} / \mathrm{v})$ aqueous ferric citrate solution. Hydrolysis of casein, tyrosine and xanthine was demonstrated in the basal media described by Gordon \& Mihm (1957, 1959). The plates were inoculated for 7 days and observed for clearing. Hydrolysis of starch was tested by means of the medium described by Gordon \& Mihm (1957) and Lugol's iodine solution.

Acid production was tested in a basal medium: Bacto-peptone (Difco), $10 \mathrm{~g}: \mathrm{KH}_{2} \mathrm{PO}_{4}$, $0.5 \mathrm{~g} ; \mathrm{MgSO}_{4} .7 \mathrm{H}_{2} \mathrm{O}$, 0.5 $\mathrm{g}$; purified agar, $20.0 \mathrm{~g}$; distilled water, $1000 \mathrm{ml}$ amended with $0.02 \%(\mathrm{w} / \mathrm{v})$ bromthymol blue, $\mathrm{pH} 7.0$. Solutions of carbohydrates were added aseptically after autoclaving to the basal medium to give a final concentration of $0.5 \%(\mathrm{w} / \mathrm{v})$ (Table 3 ). The basal medium was autoclaved at $12 \mathrm{I}{ }^{\circ} \mathrm{C}$ for $15 \mathrm{~min}$. Media were poured into tubes which were sealed with screw caps. Inoculated tubes were incubated for 7 days and acid production detected by a change in colour of the indicator. With glucose the test was done in duplicate, one tube being sealed with a layer of sterile paraffin according to Hugh \& Leifson (I953) for oxidation-fermentation test.

Collection of data. The data obtained from the 77 characters analysed were recorded as two-state characters. Multi-state, quantitative characters were turned into two-state characters and were encoded following the additive procedure (Sneath, 1957b). Entries which were missing or inapplicable were marked $\mathrm{NC}$ (no comparison).

An IBM 23 I o computer system was used for data processing which included calculation of the similarity coefficient between pairs of organisms, clustering the organisms into groups by step-wise $2.5 \%$ decrements in similarity indices, and measurement of the degree of homogeneity within and differences between the delineated clusters. Furthermore, the frequency of occurrence of the characters in clusters of taxonomic significance was tabulated.

Calculation of coefficients of association. The overall similarities between the organisms 
were calculated in two ways - by the similarity coefficient $\left(\mathbf{S}_{J}\right)$ devised by Sneath $(1957 b)$ in which negative matches are excluded and by the simple matching coefficient $\left(S_{s}\right)$ employed by Sokal \& Michener (1958) in which negative matches are included.

Cluster analysis. From the unsorted similarity matrix, clusters (phenons) were identified by the single-linkage cluster-analysis technique (SLCA) (Sneath, 1957a). The adequacy of the clusters formed by SLCA with a constant decrement of $2.5 \%$ was judged by listing the five strains most similar to each other and preparing a single-linkage phenogram (= minimum spanning tree) of the type described by Gower \& Ross (I969).

Evaluation of clusterings. The homogeneity of the clusters and the interrelationships between them were determined by calculating the intra- and intergroup similarity values.

Calculation of the variation of characters within a species. Well-defined phenons were characterized by tabulating a 'calculated median organism' (CMO) for each phenon according to Liston, Wiebe \& Cowell (1963). The CMO was taken to represent the taxonomic 'centre' of the group. The range of variation within a species was obtained by assuming that the similarity values of the strains to the CMO showed a normal distribution curve around the mean similarity value to the CMO. It was further expected that $95 \%$ of the members of a phenon will be allocated within the mean similarity value $\pm 2 x$ standard deviation. The lowest permissible similarity index for a strain to be included in the respective species was established.

Selection of diagnostic keys. By comparison of the total array of characters for each defined cluster of strains, distinguishing and determinative features suitable for providing an identification scheme were selected.

Serological analysis. Immunofluorescent staining of pure cultures were performed. High-titre antisera were produced by intravenous injection of formalin-killed bacteria into rabbits twice weekly for 4 weeks. The sera were precipitated with ammonium sulphate and the IgG was labelled with fluorescein iso-thiocyanate. Conjugated antisera, the properties of which are reported elsewhere (Holmberg \& Forsum, 1973), were prepared against Bacterionema matruchotii ATCC 14265, Rothia dentocariosa ATCC I793I, Actinomyces viscosus ATCC I 5987 serotype I (hamster strain), A. viscosus ATCC I 9246 serotype 2 (human strain) and $A$. naeslundii ATCC I 2 I04. Cross-reactions were eliminated by using appropriate dilutions or absorption.

\section{RESULTS}

\section{Arrangement of the organisms into delineated clusters}

Clusters formed by single-linkage cluster analysis (SLCA) of the data obtained on the 47 reference strains and 76 isolates by using the simple matching coefficient are shown in the dendrogram in Fig. I.

In general the dendrogram derived by SLCA with threshold levels at $2.5 \%$ intervals and that derived by a minimum spanning tree using continuous decrements, were similar. As expected there were differences between the two cluster-analysis techniques in the number of clusters and their strain contents at the different levels of similarity. However, the cluster formation by the two methods was basically the same. Thus, the construction of clusters with a constant increment of $2.5 \%$ does not seem to cause displacements in the arrangement of organisms into natural groups. Most of the bacteria (98) had clustered at $90 \%$ similarity level. The per cent similarity for each pair is shown in the similarity matrix (Fig. 2). The clusters formed at the 87.5 level seem to form natural taxonomic groups. 


\section{Demarcation of phenons belonging to the category genus}

Phenons may be formed mainly on the basis of clusters defined at the $87.5 \%$ similarity level. The five major clusters formed at this level coincided with the genera Corynebacterium, Bacterionema, Rothia, Actinomyces and Nocardia (Fig. I). These phenons were given the name carried by the numerically dominant reference strains found within the clusters.

The largest of the generic clusters consisted of 50 strains, which included 44 new isolates mainly from the respiratory and urinary tracts together with all the references strains of Corynebacterium spp., except for a strain received as Corynebacterium sp. (ATCC 1 5927) and $C$. pyogenes (ATCC 5224). This cluster is therefore called Corynebacterium. The second and third clusters contained reference strains of the genera Bacterionema and Rothia, together with five new isolates from dental plaques. The fourth and next largest cluster included the reference strains of Actinomyces and Io isolates from dental plaques. The fifth cluster comprised the reference strains of Nocardia and two new isolates from the urinary tract.

At a level of similarity of $85 \%$ the generic phenons cluster in a group containing 107 strains. A reference strain of Streptomyces azureus and six non-grouping aberrant isolates are located in this cluster. The remaining ungrouped strains appear to have little taxonomic relationships with the main body of strains under study. These strains include a reference strain of Propionibacterium acnes (Corynebacterium acnes), and the three reference strains of rapidly growing mycobacteria which do not form a distinct group. Since very few similar reference strains were included, no further analysis was justified for these organisms. Other unplaced new isolates and reference strains of Lactobacillus spp., Listeria monocytogenes, Leptotrichia buccalis, one strain of Corynebacterium pyogenes and one of Corynebacterium sp., are arranged in the dendrogram in a sequence of descending similarity index.

\section{Demarcation of phenons belonging to the taxon species}

The strains of the Corynebacterium cluster fell into four subgroups defined at the $90 \%$ similarity level or above. The major subgroup IA is formed by non-saccharolytic strains fused together above the $92.5 \%$ similarity level. The two type strains of Corynebacterium hofmannii (C. pseudodiphtheriticum) unite above $95 \%$ similarity to form a tight centre to subgroup I A. Subgroup I B contains the reference strains of the saccharolytic corynebacteria C. xerosis, $C$. ovis and $C$. striatum and is defined just above the $90 \%$ similarity level. The remaining subgroups, $\mathrm{IC}$ and $\mathrm{ID}$, are small and of no taxonomic value.

At an increment of $2.5 \%$ similarity $(87.5$ to $90 \%$ ) no subdivision occurs within the Bacterionema and Rothia clusters. Thus, it seems appropriate that these genera each contain one species, Bacterionema matruchotii and Rothia dentocariosa. Included in these species are reference strains of Leptotrichia dentium, considered to be synonymous with $B$. matruchotii and Nocardia salivae, accepted as a synonym of $R$. dentocariosa. Within the Actinomyces cluster at the $90 \%$ similarity level some subclusters are formed. The largest one, $4 \mathrm{~A}$, containing almost all the new Actinomyces isolates, includes the type strains of Actinomyces naeslundii and $A$. viscosus. These species show $92.5 \%$ similarity and the type strain of $A$. viscosus seems to differ from that of $A$. naeslundii chiefly in being catalase positive and more aerobic. Subcluster $4 \mathrm{~A}$ appears to be distinct from the two minor subclusters, $4 \mathrm{~B}$ and ${ }_{4} \mathrm{C}$, delineated at $90 \%$ similarity level. These subclusters contain the reference strains of $A$. israelii and Arachnia propionica, respectively. Little can be said about these subclusters which contain so few strains. They are, however, distinctly separated from one another and from the major subcluster.

The Nocardia cluster contains two distinct subclusters, $5 \mathrm{~A}$ and $5 \mathrm{~B}$, and one diffuse sub- 
Table 2. Mean similarity indices within and between the main clusters formed

Cluster (phenon)
I) Corynebacterium
(2) Bacterionema
(3) Rothia
(4) Actinomyces/Arachnia
(4A) A. naeslundii $A$. viscosus
(4B) Anaerobic-microaerophilic Actinomyces spp. incl. Arachnia
(5) Nocardia

No.

Cluster (phenon)

$\begin{array}{ccccccc}\text { (I) } & (2) & (3) & (4) & (4 \mathrm{~A}) & (4 \mathrm{~B}) & \\ 86 \cdot 8 \pm 6 \cdot 0 & & & & & \\ 82 \cdot 9 \pm 8 \cdot 6 & 89 \cdot 6 \pm 3 \cdot 2 & & & & \\ 83 \cdot 4 \pm 8 \cdot 0 & 84 \cdot 3 \pm 6 \cdot 5 & 9 \mathrm{I} \cdot 0 \pm 3 \cdot 2 & & & \\ 80 \cdot 9 \pm 8 \cdot 8 & 79 \cdot 0 \pm 8 \cdot 1 & 82 \cdot 6 \pm 5 \cdot 9 & 83 \cdot 9 \pm 5 \cdot 6 & & \\ 83 \cdot 0 \pm 8 \cdot 2 & 80 \cdot 0 \pm 9 \cdot 4 & 85 \cdot 2 \pm 5 \cdot 6 & \cdot & 88 \cdot 9 \pm 3 \cdot 6 & & \\ 83 \cdot 0 \pm 8 \cdot 9 & 79 \cdot 0 \pm 8 \cdot 9 & 82 \cdot 4 \pm 7 \cdot 2 & . & \cdot & 83 \cdot 5 \pm 6 \cdot 0 & \\ 82 \cdot \mathrm{I} \pm 8 \cdot 7 & 81 \cdot 6 \pm 6 \cdot 5 & 78 \cdot 8 \pm 9 \cdot 2 & 76 \cdot 6 \pm 9 \cdot \mathrm{I} & 77 \cdot 5 \pm 9 \cdot 7 & 75 \cdot 9 \pm 9 \cdot 5 & 83 \cdot 8 \pm 5 \cdot 5\end{array}$


group, ${ }_{5} \mathrm{C}$. The four type strains of Nocardia asteroides unite above the $92.5 \%$ similarity level to form a tight cluster, $5 \mathrm{~A}$. The two strains of $N$. caviae form the second distinct subgroup, $5 \mathrm{~B}$, defined above $90 \%$ similarity level. Subgroup $5 \mathrm{C}$ contains two new isolates and the reference strain $N$. pelletieri linked just above the $90 \%$ similarity level.

\section{Homogeneity and interrelationship analyses}

When the similarities were recorded without discrete $2.5 \%$ steps, and the mean similarity indices for all pairs within and between the main generic clusters and subclusters were calculated (Table 2) the highest average similarity indices were observed within Bacterionema and Rothia, $89 \cdot 6 \pm 3 \cdot 2 \%$ and $9 \mathrm{I} \cdot 0 \pm 3 \cdot 2 \%$, respectively. Bacterionema showed the closest relationship to Rothia $(84 \cdot 3 \pm 6 \cdot 5 \%)$ closely followed by Corynebacterium $(82 \cdot 9 \pm 8 \cdot 6 \%)$. Rothia showed the closest relationship to Actinomyces naeslundii $(85 \cdot 2 \pm 5 \cdot 6 \%)$, followed by Bacterionema, Corynebacterium $(83.4 \pm 8.0 \%)$ and the anaerobic-microaerophilic Actinomyces spp. including Arachnia ( $82 \cdot 4 \pm 7 \cdot 2 \%)$. Corynebacterium seems to be central to the entire group of organisms in showing absence of low similarity indices to any of the other phenons.

\section{Comparison of data by positive matches only}

In the first analysis the simple matching coefficient $\left(\mathbf{S}_{\mathrm{s}}\right)$ was employed. Many of the strains, particularly non-saccharolytic corynebacteria and certain nocardias, gave negative responses to many of the tests. The data were therefore re-examined with the use of the similarity coefficient $\left(\mathbf{S}_{\mathrm{J}}\right)$ in which only positive matches are scored. The data obtained were analysed by SLCA. Most of the bacteria (89) had now clustered at $70 \%$ similarity level. The five major clusters, which coincided in the first analysis with the genera Corynebacterium, Bacterionema, Rothia, Actinomyces and Nocardia, were recovered at $67.5 \%$ similarity. The subcluster IA was recovered, but six of the strains originally allocated to this subcluster were now placed at the periphery of the Corynebacterium cluster. It would appear that some of the high overall similarities, found within this subcluster in the first analysis, were the result of negative correlations. Subcluster $\mathrm{IC}$ was not recovered. The strains included in this subcluster and the isolate 66 were now unplaced. On the other hand, the originally unplaced isolates 5, 5I and 105 were found in the Corynebacterium cluster. Subgroup $5 \mathrm{C}$, which contained the type strain of Nocardia pelletieri and the two new isolates 59 and 60 , was not recovered. These strains and the type strain of $N$. corallina were now ungrouped. The remaining subgroups, defined by the matching coefficient were recovered in their entirety in the second analysis. Within the Actinomyces cluster the subgroup, containing Actinomyces naeslundii and $A$. viscosus was distinct and defined at or around the $75.0 \%$ similarity level. The mean intragroup similarity value was $72 \cdot 9 \pm 7 \cdot 9$. The Bacterionema and Rothia clusters were recovered as distinct clusters, defined above the $70.0 \%$ similarity level to form tight homogenous groups. The average intragroup similarity values were $68 \cdot 8 \pm 8 \cdot 8$ and $76 \cdot 0 \pm 7 \cdot 6$, respectively.

\section{Calculation of phenetic variation within the species Bacterionema matruchotii, Rothia dentocariosa and Actinomyces naeslundii/A. viscosus}

One of the important aims in defining a species is to determine the extent of the variation and this can be done by reference to the characters of a hypothetical 'calculated median organism' (CMO) which possesses the characters found in more than $50 \%$ in the group. Table 3 gives the CMOs for Bacterionema matruchotii, Rothia dentocariosa and Actinomyces naeslundii/A. viscosus. 
Table 3. The characters of the phenons of Bacterionema matruchotii, Rothia dentocariosa and Actinomyces viscosus/Actinomyces naeslundii

Characters

Cellular morphology

I. Cocco-bacillary

2. Straight rods

3. Curved rods

4. Branching

5. Pleomorphic ( $\leqq 75 \%$ in any of above categories)

6. Fusiform

7. Filamentous ( $\geqq 20: 1)$

8. Tapered cell

9. Spores present

I0. Motility

I1. Metachromatic granules present

12. Gram-negative

13. Gram-positive

14. Gram-variable $(\leqq 75 \%$ in either of above categories)

I 5. Single organisms

I6. Paired organisms

17. Chains or segments

I8. Cuniform

Colony morphology

19. Entire flat

20. Raised

2I. Convex

22. Umbonate

23. Entire edge

24. Crenated edge

25. Erosed edge

26. Fimbriated edge

27. Transparent

28. Opaque

29. White

30. Off-white to grey

31. Red/yellow

32. Pink

33. Smooth

34. Rough

35. Mucoid

Growth

36. Aerobic

37. In medium with a sole inorganic $\mathrm{N}$ source

38. In Rogosa agar

39. In tellurite media $(0.07 \%)$

40. In tellurite media $(0.3 \%)$

Biochemical tests

41. Catalase activity

42. Oxidase activity

43. Urease production

44. Indole production

45. MR test

46. VP test

47. Nitrate reduction

48. Nitrite reduction

49. Aesculin hydrolysis

50. Starch hydrolysis
B. matruchotii $R$. dentocariosa

$$
(\%)
$$

$(\%)$

A. viscosus/

$(\%)$

$(\%)$

$\begin{array}{rr}0 & \\ 0 & \\ 0 & \\ 44 & \\ 56 & \\ & \\ 0 & \\ 89 & \\ 0 & \\ 0 & \\ 0 & \\ 0 & \\ 0 & \\ 100 & \\ 0 & \\ 67 & \\ 0 & \\ 33 & \\ 0 & \end{array}$

$\begin{array}{rr}40 & 0 \\ 0 & 9 \\ 0 & 0 \\ 0 & 20 \\ 90 & 82\end{array}$

020

$40 \quad 55$

$80 \quad 45$

0

0

0

0

IOO

$90-45$

$0 \quad 0$

I0 9

$\begin{array}{lll}0 & 0 \\ 100 & 0\end{array}$

$\begin{array}{rrr}100 & 0 & 0 \\ 0 & 100 & 100\end{array}$

0000

I I $90 \quad 100$

67 IO

$0 \quad 00$

$\begin{array}{lll}0 & 0 \\ 0 & 0 & 0\end{array}$

$\begin{array}{rrr}0 & 0 & 0 \\ 100 & 100 & 100\end{array}$

$44 \quad 40 \quad 55$

$56 \quad 60 \quad 45$

o

0

22

87

0

100

0

0

II

o

o

0

80

20

o

100

o

0

50

0

45
0

0

100

0

100

0

82

0

100

$100 \quad 82$

0

o

0

85

100

I 00

100

100

o 
Table 3 (cont.)

\begin{tabular}{|c|c|c|c|}
\hline Characters & $\begin{array}{c}\text { B. matruchotii } \\
(\%)\end{array}$ & $\begin{array}{c}R . \text { dentocariosa } \\
(\%)\end{array}$ & $\begin{array}{c}\text { A. viscosus } \\
\text { A. naeslundii } \\
(\%)\end{array}$ \\
\hline \multicolumn{4}{|l|}{ Biochemical tests (cont.) } \\
\hline 5I. O-F test (oxidative + ) & 0 & 0 & 0 \\
\hline 52. Casein decomposition & 0 & 30 & 0 \\
\hline 53. Tyrosine decomposition & 0 & 0 & 0 \\
\hline 54. Xanthine decomposition & 0 & 0 & 0 \\
\hline \multicolumn{4}{|l|}{ Acid from carbohydrates } \\
\hline 55. Arabinose & 0 & 0 & 0 \\
\hline 56. Galactose & o & o & IOO \\
\hline 57. Inositol & 0 & 0 & 100 \\
\hline 58. Mannitol & I I & 0 & 0 \\
\hline 59. Mannose & 100 & 100 & 73 \\
\hline 6o. Rhamnose & 0 & o & 0 \\
\hline 6I. Sorbitol & 0 & 0 & $\mathrm{o}$ \\
\hline 62. Sucrose & 100 & 100 & 100 \\
\hline 63. Fructose & 100 & 100 & 100 \\
\hline 64. Lactose & 0 & 0 & 100 \\
\hline 65. Salicin & 22 & 70 & 64 \\
\hline 66. Xylose & 0 & 0 & 0 \\
\hline 67. Maltose & 56 & 100 & 100 \\
\hline 68. Glycerol & 33 & 90 & $9 \mathrm{I}$ \\
\hline 69. Glucose & 98 & IOO & 100 \\
\hline 70. Adonitol & 0 & 0 & 0 \\
\hline 71. Dulcitol & 0 & 0 & 9 \\
\hline 72. Erythritol & o & 0 & 0 \\
\hline 73. Alpha-methyl-D-glucoside & 0 & 30 & 0 \\
\hline 74. Raffinose & 0 & 0 & 100 \\
\hline 75. Trehalose & 0 & 100 & 100 \\
\hline 76. Aesculin & 22 & 10 & 73 \\
\hline 77. Starch & 0 & 0 & 0 \\
\hline
\end{tabular}

The lowest permissible similarity index to the $\mathrm{CMO}$, based on the matching coefficient that a strain must possess to be included in the appropriate phenetic group, will be: Bacterionema matruchotii $87.8 \%$, Rothia dentocariosa $88 . \mathrm{I} \%$, and Actinomyces naeslundii/A. viscosus $87.0 \%$ (Table 4 ). Thus these species might be defined, in terms of the 77 characters, as strains which show a similarity relationship of approx. $88 \%$ or more to the respective CMO of the phenons.

The similarity values for the members of the phenons to their respective CMO showed consistently high similarity values (Table 5 ). No member showed a similarity lower than $87 \%$. This phenotypic constancy provided further evidence for the existence of the welldefined species Bacterionema matruchotii and Rothia dentocariosa, and for the inclusion of Actinomyces naeslundii and $A$. viscosus in a single taxon.

Statistically, the CMO represents the most 'typical' strain of a species. Consequently strains designed as neotype cultures of a species should be those showing the closest similarity to the CMO. Among the reference strains the proposed neotype cultures of Bacterionema matruchotii (ATCC I4266, Gilmour, Howell \& Bibby, 196I $b$ ) and Rothia dentocariosa (ATCC I793I, Georg \& Brown, I967) were similar to the CMO in showing 90\% similarity. Within the taxon including Actinomyces naeslundii and $A$, viscosus strains, both the type strains, $A$. naeslundii, ATCC I2 I04, and $A$. viscosus, ATCC 19246, exhibited high similarity to the created CMO.

In an additional analysis, isolates not sorting in the phenons of Bacterionema matruchotii, Rothia dentocariosa and Actinomyces naeslundii/A. viscosus were screened for variants of 
Table 4. The mean similarity value for members of the phenon of Bacterionema matruchotii, Rothia dentocariosa and Actinomyces naeslundii/Actinomyces viscosus to own CMO and to the others

Mean S-value to the CMO of

Phenon

(2)

(3)

(4A)

\section{B. matruchotii}

(2)

$93 \cdot 0 \pm 2 \cdot 6$

$80 \cdot 6 \pm 3 \cdot I$

$72 \cdot 3 \pm 3 \cdot 3$
R. dentocariosa

(3)

$78 \cdot 4 \pm \mathrm{I} \cdot 6$

$94 \cdot \mathrm{I} \pm 3 \cdot \mathrm{O}$

$83 \cdot 5 \pm 2 \cdot 8$
A. naeslundii/A. viscosus

(4A)

$72 \cdot 0 \pm 3 \cdot 0$

$81 \cdot 9 \pm 2 \cdot 6$

$92 \cdot 4 \pm 2 \cdot 7$

Table 5. The similarity values to the CMOs of the phenon Bacterionema matruchotii, Rothia dentocariosa and Actinomyces viscosus/Actomyces naeslundii and FA reactions with antisera to the type-strains of these species for strains clustering in these phenons according to the overall similarity analysis

\begin{tabular}{|c|c|c|c|c|c|c|c|c|c|}
\hline \multirow[b]{3}{*}{ Phenon } & \multicolumn{4}{|c|}{$\mathrm{S}$-value to the CMO of } & \multirow{2}{*}{\multicolumn{5}{|c|}{ FA reactions with antisera to }} \\
\hline & \multirow[b]{2}{*}{$\begin{array}{c}\text { Strain } \\
\text { no. }\end{array}$} & \multirow{2}{*}{$\begin{array}{l}\text { B. matru- } \\
\text { chotii } \\
\text { (2) }\end{array}$} & \multirow{2}{*}{$\begin{array}{l}\text { R. dento- } \\
\text { cariosa } \\
\text { (3) }\end{array}$} & \multirow{2}{*}{$\begin{array}{l}\text { A. viscosus/ } \\
\text { A. naeslundii } \\
\quad(4 \mathrm{~A})\end{array}$} & & & & & \\
\hline & & & & & $\begin{array}{r}\text { ATCC } \\
\text { I } 4265\end{array}$ & $\begin{array}{r}\text { ATCC } \\
\text { I } 793 \text { I }\end{array}$ & $\begin{array}{r}\text { ATCC } \\
15987\end{array}$ & $\begin{array}{r}\text { ATCC } \\
19246\end{array}$ & $\begin{array}{r}\text { ATCC } \\
12104\end{array}$ \\
\hline \multirow[t]{9}{*}{2} & 28 & 94 & 78 & 69 & + & - & - & - & - \\
\hline & 37 & 91 & 78 & 74 & + & - & - & - & - \\
\hline & 39 & 95 & 78 & 69 & + & - & - & - & - \\
\hline & 26 & 94 & 78 & 74 & + & - & - & - & - \\
\hline & $3 \mathbf{I}$ & $9 \mathrm{I}$ & 77 & 73 & + & - & - & - & - \\
\hline & I 4265 & 91 & 78 & 72 & + & - & - & - & - \\
\hline & I $4266^{*}$ & 95 & 78 & 69 & + & - & - & - & - \\
\hline & I94I9 & 96 & $8 \mathrm{I}$ & 71 & + & - & - & - & - \\
\hline & 10206 & 87 & 82 & 78 & + & - & - & - & - \\
\hline \multirow[t]{10}{*}{3} & 40 & 84 & 95 & 82 & - & + & - & - & - \\
\hline & 33 & $8 \mathrm{I}$ & 96 & 81 & - & + & - & - & - \\
\hline & $4 \mathrm{I}$ & 84 & $9 \mathrm{I}$ & 79 & - & + & - & - & - \\
\hline & 45 & 79 & 94 & 84 & - & + & - & - & - \\
\hline & 46 & 82 & 94 & 87 & - & + & - & - & - \\
\hline & $1793 I^{*}$ & $8 I$ & 95 & 78 & - & + & - & - & - \\
\hline & 14189 & 83 & 95 & 83 & - & + & - & - & - \\
\hline & 14190 & $8 I$ & 100 & 83 & - & + & - & - & - \\
\hline & $1419 \mathrm{I}$ & 78 & 95 & $8 I$ & - & + & - & - & - \\
\hline & 10207 & 74 & 88 & 82 & - & + & - & - & - \\
\hline \multirow[t]{11}{*}{$4 \mathrm{~A}$} & 29 & 70 & 82 & 92 & - & - & - & + & - \\
\hline & 30 & 65 & 77 & 87 & - & - & - & - & + \\
\hline & 34 & 75 & 84 & 90 & - & - & - & + & - \\
\hline & 38 & 73 & 87 & 92 & - & - & - & + & - \\
\hline & 42 & 74 & 83 & $9 \mathrm{I}$ & - & - & - & + & - \\
\hline & 43 & 77 & 86 & 94 & - & - & - & + & - \\
\hline & 44 & 71 & 83 & 94 & - & - & - & - & + \\
\hline & $12104 *$ & 71 & 83 & 96 & - & - & - & - & + \\
\hline & I $5987^{*}$ & $7 \mathrm{I}$ & 85 & 94 & - & - & + & - & - \\
\hline & I 5988 & 77 & 83 & 91 & - & - & + & - & - \\
\hline & $19246^{*}$ & 71 & 85 & 91 & - & - & - & + & - \\
\hline
\end{tabular}


these species by comparison with the CMOs. All strains, however, exhibited similarity values to the CMOs falling outside a $5 \%$ range from the permissible low limits.

\section{Indentification by immunofluorescence}

All isolates were also examined by immunofluorescent staining with FITC-conjugated antisera to the type strains of Bacterionema matruchotii, Rothia dentocariosa, Actinomyces naeslundii and $A$. viscosus. All new isolates grouping within $B$. matruchotti or $R$. dentocariosa showed positive fluorescence in tests with conjugates to the type strains of the respective species but negative reactions to the Actinomyces conjugates (Table 5).

The isolates which associated in the Actinomyces naeslundii species showed positive immunofluorescent staining to either $A$. viscosus, serotype 2 (ATCC 19246) or A. naeslundii (ATCC I2104) antisera. Five isolates showed positive immunofluorescence with $A$. viscosus serotype 2 conjugate and two with $A$. naeslundii conjugate, but all exhibited negative immunofluorescence with $A$. viscosus serotype I (ATCC I5987) conjugate. All other isolates were negative to these antisera and the other sera tested.

\section{Diagnostic key}

The second main aim of this investigation was to use the numerical method to select diagnostic tests for the construction of determinative keys for the identification of Bacterionema matruchotii, Rothia dentocariosa, Actinomyces naeslundii and $A$. viscosus. By comparing the frequencies of occurrence for the total array of characters within each defined phenetic group such characters could be discerned (Table 6). Those phenotypic characters most useful for an identification scheme are extracted in Table 7 .

\section{DISCUSSION}

The coefficient of association employed in the first analysis included negative matches. In taxonomy, negative matches are considered just as important as positive ones (Sokal \& Sneath, 1963). Furthermore, evidence has accumulated that inclusion of negative matches may produce sharper group demarcation (Hill, Turri, Gilardi \& Silvestri, I961; Beers \& Lockhart, 1962). There is, however, a risk that strains may be clustered together as a result of many negative correlations. In the comparative study the SLCA of data obtained from the similarity coefficient and that of data obtained from the matching coefficient gave almost identical results, but with the matching coefficient a few strains were grouped with the Corynebacterium cluster and the Nocardia cluster on the basis of negative correlations. The clusters, Bacterionema, Rothia and Actinomyces naeslundii/A. viscosus, were recovered in their entirety when only positive matches were scored. Thus the strains of these clusters were not grouped together because of an overwhelming majority of shared negative correlation. It would, however, appear that the inclusion of negative features contributed to the high similarity values in the first analysis.

The single-linkage cluster-analysis technique used for identifying natural groupings from similarity matrices may suffer from 'chaining', giving clusters feebly linked internally (e.g. Bergan, I97 I Jardine \& Sibson, I97I). Strains may be included in a cluster as a result of high similarity to only one or two members of that group. However, in this study the clusters reappeared as distinct clusters when picked out by a minimum spanning tree, and the listing of the five strains most similar to each strain revealed that the clusters were well linked internally. Furthermore, the validity of the SLCA-clusters, the genus and the species, 
were confirmed by the results of homogeneity tests, calculating the means of the intragroup similarity and intergroup similarity values.

The similarity groupings revealed five major phenetic groups belonging to the category 'genus'. According to the grouping of the reference strains these main phenons corresponded taxonomically to classical generic taxa of Corynebacterium, Bacterionema, Rothia, Actinomyces and Nocardia, with interrelationships which in the main coincide with the taxonomic and phylogenetic relationships of members of the order Actinomycetales proposed by Pine \& Georg (I965) and by Pine (1970). There is no general agreement on the taxonomy of the family Corynebacteriaceae. The findings in the present study do not support the suggestion by Harrington (I966) for a common new genus for Corynebacterium, Nocardia and Mycobacterium, but agree with the results of recent taxonomic studies on coryneform bacteria by Davis \& Newton (1969) and Bousfield (1972), where the generic differences of these organisms are emphasized. However, certain coryneform taxa, e.g. Brevibacterium and Microbacterium cannot yet be clearly distinguished from the genera Nocardia and Mycobacterium. Other coryneform genera, e.g. Listeria, Erysipelothrix, Kurthia, are recognized to show little similarity to the actinomycetes.

It would appear that the genus Corynebacterium is heterogeneous. It has been suggested that Corynebacterium pyogenes and also $C$. haemolyticum should be removed from the genus on the ground that they have too little in common with the type species (Barksdale, 1970). Other animal strains may form a satisfactory group (Bousfield, 1972) readily distinguished from the actinomycetes. A division into saccharolytic and a non-saccharolytic species has been recommended (Morris, I954; Moore \& Davis, I963; Harrington, 1964) and the separation of a large subgroup of non-saccharolytic corynebacteria, resembling $C$. hofmannii, appears to be convenient. The present work supports the concept of a species containing non-saccharolytic corynebacteria.

The taxonomic relationships found between the Nocardia species seem to be in reasonable agreement with recent numerical classifications (Tsukamura, I969; Goodfellow, 197I). The type strains of Nocardia asteroides and $N$. caviae formed distinct taxospecies. Nocardia brasiliensis and also $N$. rubra were located in the Nocardia cluster. The species $N$. pelletieri and $N$. corallina joined the cluster due to negative correlations, but had little affinity to the Nocardia cluster when only positive matches were scored.

The Actinomyces cluster was somewhat ill defined. Nevertheless, the microaerophilic to anaerobic species $A$. israelii and Arachnia propionica appeared to be distinct from the facultative to aerobic Actinomyces species. These results support the suggestion by Lechevalier \& Lechevalier (1967) that one should distinguish the aerobic actinomycetes from the anaerobic-microaerophilic ones. The reference strain of Arachnia propionica, originally described as Actinomyces propionicus (Buchanan \& Pine, I962), appeared in the Actinomyces cluster. The proposal for a new genus, Arachnia, was based on metabolic products and wall composition (Pine \& Georg, 1969).

The taxonomic position of both Actinomyces naeslundii and $A$. viscosus within the same phenon is a result which is in good agreement with those of Melville (I965) who found a main phenon suggested by overall similarity values of oral actinomycetes that conformed to the description of $A$. naeslundii, except that some strains grew easily under aerobic condition and produced catalase. Probably these later strains consisted of strains which would now be called $A$. viscosus. These results support the view that $A$. viscosus be considered a catalasepositive variant of $A$. naeslundii (Gerencser \& Slack, 1969). However, differences in wall composition and antigens have helped to maintain these organisms as two separate species (Gerencser \& Slack, 1969). Studies have indicated the pathogenicity of $A$. naeslundii to be 
Table 6. Incidence of potentially diagnostic markers in the major groups discernible by single-linkage clustering

Character

Cellular morphology

Cocco-bacillary

Straight rods $(\leqslant 20: I)$

Curved rods

Branching

Pleomorphic

Fusiform

Filamentous $(\geqslant 20: I)$

Tapered cell

Spores present

Motility

Metachromatic granules

Gram-negative

Gram-positive

Gram-variable

Single organisms

Paired organisms

Chains or segments

Cuniform arrangement

Colony morphology

Entire effuse (flat)

Raised

Convex

Umbonate

Entire edge

Crenated edge

Erose edge

Fimbriated edge

Transparant

Opaque

White

Off-white to grey

Red/yellow

Pink

Smooth

Rough

Mucoid

Growth

Aerobic growth

On media with inorganic

$\mathrm{N}$ source

On Rogosa's ager

On tellurite media $(0.07 \%)$

On tellurite media $(0.3 \%)$

Biochemical tests

Catalase activity

Oxidase activity

Urease activity

Indole production

MR test

VP test
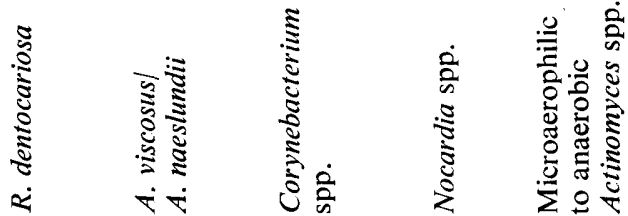

$\begin{array}{lll}\overline{\mathrm{d}} & - & - \\ \mathrm{d} & - & - \\ \overline{\mathrm{d}} & \overline{\mathrm{d}} & - \\ \overline{-} & \overline{\mathrm{d}} & - \\ \overline{\mathrm{d}} & \mathrm{d} & \mathrm{d} \\ \overline{-} & - & - \\ \overline{\mathrm{d}} & - & - \\ \mathrm{d} & - & - \\ \overline{+} & - & - \\ - & + & + \\ - & - & - \\ - & \mathrm{d} & + \\ \overline{-} & - & - \\ + & - & -\end{array}$

$\begin{array}{lll}+ & + & \mathrm{d} \\ - & - & - \\ - & - & + \\ - & - & - \\ \mathrm{d} & \mathrm{d} & \mathrm{d} \\ + & + & -\end{array}$

\begin{tabular}{lll}
+ & + & - \\
\hdashline & - & - \\
$d$ & + & - \\
$d$ & - & - \\
$d$ & - & -
\end{tabular}


Table 6. (cont.)

Character

Biochemical tests (cont.)

Nitrate reduction

Nitrite reduction

Aesculin hydrolysis

Starch hydrolysis

O-F test (oxidative + )

Casein decomposition

Tyrosine decomposition

Xanthine decomposition

Acid from carbohydrates

Arabinose

Galactose

Inositol

Mannitol

Mannose

Rhamnose

Sorbitol

Sucrose

Fructose

Lactose

Salicin

Xylose

Maltose

Glycerol

Glucose

Adonitol

Dulcitol

Erythritol

Alpha-methyl-D-glucoside

Raffinose

Trehalose

Aesculin

Starch
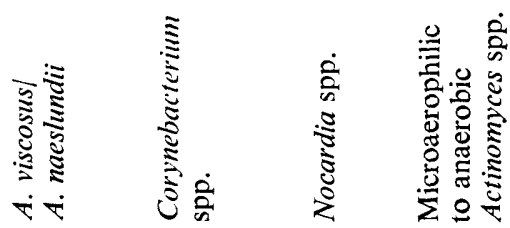

$\begin{array}{lll}\mathrm{d} & \mathrm{d} & \mathrm{d} \\ \mathrm{d} & - & - \\ - & + & \mathrm{d} \\ \mathrm{d} & - & \mathrm{d} \\ -(\mathrm{NC})^{*} & + & - \\ - & \mathrm{d} & - \\ - & \mathrm{d} & - \\ - & - & \end{array}$

$\begin{array}{ll}\bar{d} & - \\ - & \mathrm{d} \\ \bar{d} & \mathrm{~d} \\ - & \mathrm{d} \\ \overline{-} & \mathrm{d} \\ \mathrm{d} & \mathrm{d} \\ \mathrm{d} & \mathrm{d} \\ - & - \\ - & - \\ - & - \\ \mathrm{d} & \mathrm{d} \\ \mathrm{d} & + \\ \mathrm{d} & + \\ - & - \\ - & - \\ - & - \\ - & - \\ - & - \\ \mathrm{d} & - \\ - & - \\ - & -\end{array}$

,+ 9 I to $100 \%$ of strains positive; d, I I to $90 \%$ positive;,- 0 to $10 \%$ positive.

* Non-saccarolytic corynebacteria.

comparable with that of $A$. israelii (Coleman \& Georg, 1969; Coleman, Georg \& Rozzell, 1969; Georg \& Coleman, 1970). However, no clear relationship of $A$. viscosus to human infections has been shown.

Taxonomically and serologically the strains of Rothia formed a distinct and independent group. Evidence for separation of the species Rothia dentocariosa from other Gram-positive filamentous organisms on the basis of a unique fructose-containing wall antigen has also been documented in a recent study (Hammond, I970 a). Moreover, a comparison of the GC ratio of the DNA of $R$. dentocariosa from diverse origins has revealed a reasonably homogeneous group. On this basis isolated coccal variants of $R$. dentocariosa have also been considered to be in the same taxonomic group as the filamentous ones (Hammond, I970 $b$ ). In addition, the results which showed a clear relationship between Rothia and the genus Actinomyces thus confirm the retention of the genus Rothia in the family Actinomycetaceae. 
Table 7. Identification scheme for Actinomyces naeslundii, A. viscosus, Bacterionema matruchotii and Rothia dentocariosa

Feature

Species

Aerobic growth

$\mathrm{O}-\mathrm{F}$ test

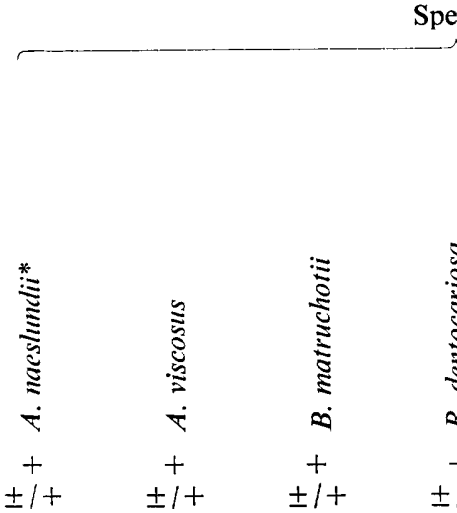

Growth in a medium with ammonium ions as sole source of nitrogen Growth on Rogosa's agar Aesculin hydrolysis Acid from lactose VP test

Nitrite reduction Starch hydrolysis Catalase production

\begin{tabular}{|c|c|c|}
\hline 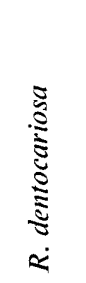 & 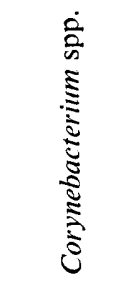 & 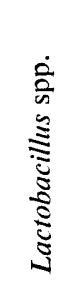 \\
\hline+ & $\begin{array}{c}+ \\
\pm 1+ \\
\text { or }-1-\dagger\end{array}$ & $\stackrel{+}{ \pm 1+}$ \\
\hline- & - & - \\
\hline- & - & + \\
\hline+ & - & d \\
\hline- & - & d \\
\hline+ & $\mathrm{d}$ & d \\
\hline+ & $\mathrm{d}$ & $\mathrm{d}$ \\
\hline- & d & $\mathrm{d}$ \\
\hline+ & + & - \\
\hline
\end{tabular}

+ , positive; - , negative; d, doubtful; w, weak reaction.

* Optimal aerobic growth in presence of $\mathrm{CO}_{2}$.

$\dagger$ Non-saccharolytic Corynebacterium spp.

Bacterionema matruchotii appeared as a distinct taxonomic species-group and showed distinctive serological features in immunofluorescence. Moreover, B. matruchotii strains can be separated from other filamentous organisms serologically in agglutination tests (Snyder, Slawson, Bullock \& Parker, 1967) and they possess a distinctive wall composition (Davis \& Freer, I960). Although the Bacterionema matruchotii group constitutes a recognizable taxonomic entity its generic location is still unsettled. Bacterionema matruchotii strains show a closer taxonomic affinity to Corynebacterium and Nocardia than to actinomycetes. Recently Pine (1970) suggested the family Corynebacteriaceae as more suitable for B. matruchotii on the basis of its propionic acid fermentation (Howell \& Pine, I96r). Further work is needed to see if the Bacterionema group deserves recognition as a genus, and to establish the relationship of the taxon with coryneform and nocardioform bacteria.

The methods of numerical taxonomy which depend on the utilization of a broad range of tests can be used to produce determinative keys based on a few characters (e.g. Lockhart \& Liston, 1970). A number of characters can be selected from each defined cluster to provide identification of an organism, taking into account the expected variations in characteristic between strain of a species or species of a genus. In the present study, all the strains were found to be Gram-positive, non-sporing and non-motile but rather pleomorphic. This morphology is affected by several factors such as the age of the culture and the composition of the medium (Jordan \& Howell, 1965; Georg, 1970). Bacterionema matruchotii and Rothia dentocariosa form bacillary and coccoidal organisms and thus appear to be unique among the actinomycetes 
(Brown et al. 1969; Hammond, I970 a; Streckfuss \& Smith, I970). In classical taxonomy the order Actinomycetales is based on the morphological criterion of true branching. The data obtained from the cellular morphology techniques used in the present study do not support the inclusion of morphological criteria as parameters to reveal the identity of $B$. matruchotii, Rothia dentocarisoa, Actinomyces naeslundii and $A$. viscosus. The results indicated, however, that various physiological, biochemical and fermentation studies could be utilized.

The corynebacteria and nocardia consistently required aerobic conditions for growth. Bacterionema matruchotii, Rothia dentocariosa and Actinomyces viscosus also grew aerobically. Actinomyces naeslundii, on the other hand, needed the presence of $\mathrm{CO}_{2}$ for good aerobic growth. Good aerobic growth on initial isolation differentiate all these organisms from A. odontolyticus, microaerophilic to anaerobic Actinomyces spp., and from Propionibacterium acnes. Although $A$. odontolyticus grew anaerobically on initial isolation, most strains grew quite well aerobically with or without $\mathrm{CO}_{2}$ after several subcultures in the laboratory.

A negative catalase activity differentiated Actinomyces naeslundii from $A$. viscosus and also excluded A. odontolyticus, anaerobic Actinomyces spp., Arachnia propionica and other related organisms such as lactobacillii.

Bacterionema matruchotii, Rothia dentocariosa, all Actinomyces spp. and most corynebacteria failed to grow in media containing ammonium ions as the sole nitrogen source. The ready fermentation of sugars with production of acid differentiated these species from nocardias. Nocardia, rapidly growing mycobacteria and streptomycetes grew well on media with an inorganic nitrogen source and oxidized but did not ferment sugars (Tsukamura, I967; Gordon, 1967; Tsukamura, 1969; Goodfellow, 1971).

The corynebacteria were also unable to hydrolyse aesculin, whereas most Bacterionema, Rothia dentocariosa, Actinomyces naeslundii and Actinomyces viscosus strains promptly hydrolysed aesculin. These characteristics are in agreement with earlier reports (Moore \& Davis, 1963; Brown et al. 1969; Gerencser \& Slack, I969; Smith, 1969). It is notable that corynebacteria could be separated from the other groups not only by their failure to hydrolyse aesculin and a more rapid aerobic growth, but also by their inability to form acid from lactose. No true Corynebacterium strains are lactose-positive (Barksdale, 1970).

An outstanding feature of Rothia dentocariosa, in contrast to Bacterionema matruchotii, was the inability to hydrolyse starch and the ability to reduce nitrite. This ability of $R$. dentocariosa to reduce nitrite has been suggested as a criterion for differentiating between Actinomyces viscosus and $R$. dentocariosa (Brown et al. 1969). Our results do not support this opinion (previously questioned by Gerencser \& Slack, 1969) because nitrite reduction and starch hydrolysis seemed to be variable in $A$. naeslundii and $A$. viscosus.

Other cluster-specific biochemical characters with presumptive diagnostic value are the urease and Voges-Proskauer tests. All strains of Actinomyces naselundii and A. viscosus showed urease activity. This result contradicts the findings in other studies on Actinomyces spp. (e.g. Coleman et al. 1969; Gerencser \& Slack, 1969), a discrepancy which may depend on the media used. A suppression of urease formation by other more readily utilizable nitrogen sources than urea might have prevented the urease from being detected (Krämer \& Schlegal, 1967) or the medium devised by Christensen (1946), used in this study, might have had a weaker buffering capacity which results in registering of lower urease activity. A positive Voges-Proskauer test was a consistent finding for Bacterionema matruchotii and Rothia dentocariosa, distinguishing these species from $A$. naeslundii and $A$. viscosus. However, Brown et al. (1969) reported the Voges-Proskauer test with $R$. dentocariosa to be neither consistent nor reproducible. On the contrary, Davis \& Freer (I960) found the Voges- 
Proskauer test positive for this species in basal media with $2 \%(\mathrm{w} / \mathrm{v})$ glucose, and considered a fairly high glucose concentration as important for positive results.

The fermentative pattern also seems useful in differentiating these species. The capacity of the actinomyces to ferment lactose and raffinose distinguish them from Bacterionema matruchotii and Rothia dentocariosa. $R$. dentocariosa, Actinomyces naeslundii and $A$. viscosus produce acid from glycerol and trehalose but strains of $B$. matruchotii do not. Most of these fermentative features are consistent with characters ascribed to these species by other workers (Davis \& Freer, 1960; Gilmour \& Beck, 196I; Roth \& Thurn, I962; Georg \& Brown, 1967; Brown et al. 1969; Gerencser \& Slack, 1969) although not considered in combination to differentiate between species.

Thus a set of reproducible tests could be extracted for a convenient diagnostic scheme, providing identification of Bacterionema matruchotii, Rothia dentocariosa, Actinomyces naeslundii and $A$. viscosus in the presence of diagnostically confusing bacteria in initial aerobic isolation.

In practice, samples are streaked on appropriate growth media, e.g. NAYS-agar and incubated with $\mathrm{CO}_{2}$ at $37^{\circ} \mathrm{C}$ for 4 to 5 days. The plates are searched for colonies of Grampositive filamentous and/or diphtheroid organisms. Staining also gives information on size, shape and arrangement of cells, and possible spore formation. Selected colonies are transferred to fresh media and incubated for another period of 2 to 5 days. Pure subcultures are subjected to a set of test media for oxygen tolerance, $\mathrm{O}-\mathrm{F}$ test, growth on an inorganic nitrogen source, acid from lactose, aesculin hydrolysis, nitrite reduction, VP test, starch hydrolysis and catalase activity. These tests have been selected because they give conclusive results, are very easy to perform and can be carried out in laboratories with limited resources and equipment. These characters will usually be sufficient for identification of Gram-positive filamentous and/or diphtheroid organisms which belong to the above species.

This investigation was supported by a grant for medical research from Västmanlands Läns Landsting, Sweden.

\section{REFERENCES}

Barksdale, L. (1970). Corynebacterium diphtheriae and its relatives. Bacteriological Review 34, 378-422. BeERs, R. J. \& LockharT, W. R. (I962). Experimental methods in computer taxonomy. Journal of General Microbiology 28, 633-640.

Bergan, T. (I97I). Survey of numerical techniques for grouping. Bacteriological Review 35, 379-389.

Bowen, W. H. B. (1959). Oral Actinomyces and Their Possible Role in Calculus Formation. Thesis. University of Rochester, Rochester, New York.

Brown, J. M., GeorG, L. K. \& WATERS, L. C. (I969). Laboratory identification of Rothia dentocariosa and its occurrence in human clinical materials. Applied Microbiology 17, I 50-I 56.

Bousfield, I. J. (1972). A taxonomic study of some coryneform bacteria. Journal of General Microbiology 7r, $44 \mathrm{I}-455$.

Buchanan, B. B. \& PINE, L. (1962). Characterization of a propionic acid producing actinomycete, Actinomyces propionicus, sp. nov. Journal of General Microbiology 28, 305-323.

Christensen, W. B. (I946). Urea decomposition as a means of differentiating Proteus and paracolon cultures from each other and from Salmonella and Shigella types. Journal of Bacteriology 52, 461-466.

Coleman, R. M. \& George, L. K. (I969). Comparative pathogenicity of Actinomyces naeslundii and Actionomyces israelii. Applied Microbiology 18, 427-432.

Coleman, R. M., Georg, L. K. \& Rozzell, A. R. (1969). Actinomyces naeslundii as an agent of human actinomycosis. Applied Microbiology 18, 420-426.

CowAN, S. T. \& STEEL, K. J. (I966). Manual for the Identification of Medical Bacteria. Cambridge: Cambridge University Press.

Davis, G. H. G. \& Baird-Parker, A. C. (1959). The bacterial elements of materia alba. British Dental Journal ro6, I42-I46. 
Davis, G. H. G. \& FreER, J. H. (I960). Studies upon an oral aerobic actinomycete. Journal of General Microbiology 23, $163-178$.

Davis, G. H. G. \& Newton, K. G. (1969). Numerical taxonomy of some named coryneform bacteria. Journal of General Microbiology 56, 195-2I4.

GerenCSER, M. A. \& SlACK, J. M. (1967). Isolation and characterization of Actinomyces propionicus. Journal of Bacteriology 94, I09-I I 5.

Gerencser, M. A. \& Slack, J. M. (1969). Identification of human strains of Actinomyces viscosus. Applied Microbiology $\mathbf{1 8}, 80-87$.

GEORG, K. L. (1970). Diagnostic procedures for the isolation and identification of the etiologic agents of actinomycosis. In Proceedings International Symposium on Mycoses pp. 7 I-8o. Washington, D.C.: World Health Organization.

Georg, L. K. \& Brown, J. M. (1967). Rothia, gen. nov., an aerobic genus of the family Actinomycetaceae. International Journal of Systematic Bacteriology 17, 79-88.

GeorG, L. K. \& Coleman, R. M. (I970). Comparative pathogenicity of various Actinomyces species. In The Actinomycetales, pp. 35-45. Edited by H. Prauser. Jena: Gustav Fischer.

Georg, L. K., Pine, L. \& Gerencser, M. A. (I969). Actinomyces viscosus (Comb. nov.); a catalase-positive, facultative member of the genus Actinomyces. International Journal of Systematic Bacteriology r9, 29I293.

Gilmour, M. N. \& Beck, P. H. (1961). The classification of organisms termed Leptotrichia (Leptothrix) buccalis. III. Growth and biochemical characteristics of Bacterionema matruchotii. Bacteriological Reviews 25, I52-16I.

Gilmour, M. N., Howell, A., Jun. \& Bibby, B. G. (I96I $a$ ). The classification of organisms termed Leptotrichia (Leptothrix) buccalis. I. Review of the literature and proposed separation into Leptotrichia buccalis Trevisan, 1879 and Bacterionema gen.nov., B. matruchotii (Mendel, 19I7). comb.nov. Bacteriological Review 25, I3I-I4I.

Gilmour, M. N., Howell, A. Jun., \& BibBy, B. G. (I96I b). Proposal for designation of neotype strains of Septotrichia buccalis and Bacterionema matruchotit. International Bulletin of Bacteriological Nomenclature and Taxonomy 11, 16I-164.

Gordon, R. E. (1967). The taxonomy of soil bacteria. In The Ecology of Soil Bacteria. Edited by T. R. G. Gray and D. Parkinson. Liverpool: Liverpool University Press.

Gordon, R. E. \& Miнм, J. M. (1957). A comparative study of some strains received as nocardiae. Journal of Bacteriology 73, $15-27$.

Gordon, R. E. \& Minm, J. M. (1959). A comparison of four species of mycobacteria. Journal of General Microbiology 21, 736-748.

Goodfellow, M. (197I). Numerical taxonomy of some nocardioform bacteria. Journal of General Microbiology 69, 33-80.

Gower, J. C. \& Ross, G. J. S. (1969). Minimum spanning trees and single-linkage cluster analysis. Applied Statistics $\mathbf{r} 8,54-56$.

Grüter, W. (1932). Eine Pilzgeschwulst (Aktinomykose) in oberen Tränenröhrchen. (Actinomyces discofoliatus). Zeitschrift für Augenheilkunde 79, 477-5IO.

HAMmOND, B. F. (I970a). Isolation and serological characterization of a cell wall antigen of Rothia dentocariosa. Journal of Bacteriology 103, 634-640.

Hammond, B. F. (1970 b). Deoxyribonucleic acid base composition of Rothia dentocariosa as determined by thermal denaturation. Journal of Bacteriology ro3, 1024-1026.

Harrington, B. J. (1964). The Taxonomy of Oral Corynebacteria. Thesis, University of Birmingham.

HARRINGTON, B. J. (I966). A numerical taxonomical study of some corynebacteria and related organisms. Journal of General Microbiology 45, 3I-40.

Hill, L. R., Turri, M., Gilardi, E. \& Silverstri, L. (I96I). Quantitative methods in the systematics of Actinomycetales. II. General Microbiology 9, 56-72.

Holding, A. J. \& Collee, J. G. (197I). Routine biochemical tests. In Methods in Microbiology, pp. I-32. Edited by J. R. Norris and D. W. Ribbons. London and New York: Academic Press.

HolmberG, K. \& Forsum, U. (1973). Identification of Actinomycetes, Arachnia, Bacterionema, Rothia and Proprionibacterium species by defined immunofluorescence. Applied Microbiology. (In the press.)

HolmberG, K. \& Hallander, H. O. (1972). Interference between Gram-positive microorganisms in dental plaque. Journal of Dental Research 5I, 588-595.

Howell, A., Jordan, H. V., Georg, L. K. \& Pine, L. (1965). Odontomyces viscosus, gen. nov., spec. nov., a filamentous microorganism isolated from periodental plaque in hamsters. Sabouraudia 4, 65-68. 
Howell, A. \& PINE, L. (196I). The classification of organisms termed Leptotrichia (Leptothrix) buccalis. IV. Physiological and biochemical characteristics of Bacterionema matruchotii. Bacteriological Reviews 25, $162-171$.

Howell, A., Stephan, R. M. \& Paul, F. (1962). Prevalence of Actinomyces israelii, A. naeslundii, Bacterionema matruchotti and Candida albicans in selected areas of the oral cavity and saliva. Journal of Dental Research 4I, I050-1059.

HuGH, R. \& LeIFSON, E. (I953). The taxonomic significance of fermentative versus oxidative metabolism of carbohydrates by various Gram-negative bacteria. Journal of Bacteriology 66, 24-26.

JARDINE, N. \& Sibson, R. (I97I). Mathematical Taxonomy. London: John Wiley and Sons.

JoRDAN, H. V. \& Howell, A. (1965). Nutritional control of cellular morphology in an aerobic actinomycete from the hamster. Journal of General Microbiology 38, 125-130.

Jordan, H. V., Keyes, P. H. \& Bellack, S. (1972). Periodontal lesions in hamsters and gnotobiotic rats infected with actinomyces of human origin. Journal of Periodontal Research 7, 21-28.

KrämER, J. \& SCHLEGEL, H. G. (1967). Die Bedeutung der Ureaserepression für die taxonomische Klassifizierung von Bakterien. Zentralblatt für Bakteriologie (Abteilung II) r21, 414-423.

Lechevalier, H. A. \& Lechevalier, M. P. (1967). Biology of actinomycetes. Annual Review of Microbiology 2I, $7 \mathrm{I}-\mathrm{IOO}$.

Liston, J., Wiebe, W. \& Colwell, R. R. (I963). Quantitative approach to the study of bacterial species. Journal of Bacteriology 85, I06I-1070.

Lockhart, W. R. \& Liston, J., Eds. (1970). Methods for Numerical Taxonomy. Bethesda, Maryland: American Society for Microbiology.

Melville, T. H. (1965). A study of the overall similarity of certain actinomycetes mainly of oral origin. Journal of General Microbiology 40, 309-315.

MoORE, K. \& DAvis, G. H. G. (1963). Taxonomy and incidence of oral corynebacteria. British Dental Journal II4, 254-258.

MorRIS, E. O. (1954). The bacteria of the oral cavity. V. Corynebacteria and Gram-positive filamentous organisms. British Dental Journal 97, 29-34.

ONISI, M. (1949). Study on the Actinomyces isolated from the deeper layers of carious dentine. Shikagaku Zasshi 6, 273-282.

PINe, L. (1970). Classification and phylogenetic relationship of microaerophilic actinomycetes. International Journal of Systematic Bacteriology 20, 445-474.

Pine, L. \& Georg, L. K. (1965). The classification and phylogenetic relationship of the Actinomycetales. International Bulletin of Bacteriological Nomenclature and Taxonomy 15, I53-164.

Pine, L. \& GeorG, L. K. (1969). Reclassification of Actinomyces propionicus. International Journal of Systematic Bacteriology 19, 267-272.

Rasmussen, E. G., Gibbons, R. J. \& Socransky, S. S. (I966). A taxonomic study of fifty Gram-positive anaerobic diphtheriods isolated from the oral cavity of man. Archives of Oral Biology II, 573-579.

Rотн, G. D. (1957). Proteolytic organisms of the carious lesion. Oral Surgery, Oral Medicine and Oral Pathology 10, I105-1117.

Roth, G. D. \& FlanaGan, V. (1969). The pathogenicity of Rothia dentocariosa inoculated into mice. Journal of Dental Research 48, 957-958.

Roth, G. D. \& Thurn, A. N. (I962). Continued study of oral Nocardia. Journal of Dental Research 4I, I279-I 292.

S LACK, J. M. (1968). Subgroup on Taxonomy of Microaerophilic Actinomycetes. Report on organization, aims and procedures. International Journal of Systematic Bacteriology 18, 253-262.

Slack, J. M. \& Gerencser, M. A. (I970a). The genus Actinomyces. In The Actinomycetales, pp, 19-27. Edited by H. Prauser. Jena: G. Fischer Verlag.

SLACK, J. M. \& GerencSER, M. A. (1970 b). Two new serological groups of Actinomyces. Journal of Bacterio$\log y$ 103, 266-267.

Slack, J. M., LANDFRIEd, S. \& GerenCSER, M. A. (1969). Morphological, biochemical and serological studies on 64 strains of Actinomyces israelii. Journal of Bacteriology 97, 873-884.

SMith, R. F. (1969). Characterization of human cutaneous lipophilic diphtheroids. Journal of General Microbiology 55, 433-443.

SNeAth, P. H. A. (1957a). Some thoughts on bacterial classification. Journal of General Microbiology 17, I 84-200.

SNeATH, P. H. A. (1957b). The application of computers to taxonomy. Journal of General Microbiology 17, $201-226$. 
SNyder, M. L., Bullock, W. W. \& PARker, R. B. (1967). Morphology of Gram-positive filamentous bacteria identified in dental plaque by fluorescent antibody technique. Archives of Oral Biology r2, I 269-I 273.

Snyder, M. L., Slawson, M. S., Bullock, W. \& Parker, R. B. (I967). Studies on oral filamentous bacteria. II. Serological relationships within the genera Actinomyces, Nocardia, Bacterionema and Leptotrichia. Journal of Infectious Diseases 117, 341-345.

Socransky, S. S., Hubersak, C. \& Propas, D. (1970). Induction of periodontal destruction in gnotobiotic rats by human oral strain of Actinomyces naeslundii. Archives of Oral Biology 15, 993-995.

Sokal, R. R. \& Michener, C. D. (I958). A statistical method for evaluating systematic relationships. Kansas University Science Bulletin 38, I409-1438.

Sokal, R. S. \& Sneath, P. H. A. (1963). Principles of Numerical Taxonomy. San Francisco: W. H. Freeman. Streckfuss, J. L. \& SMith, W. N. (1970). Isolation of bacillary and streptococcal variants from Bacterionema matruchotii. Journal of Bacteriology ro4, I 399-I 400 .

Thompson, L. \& Lovestedt, S. A. (I95I). An actinomyces-like organism obtained from the human mouth. Mayo Clinic Proceedings 26, I69-175.

TSUKAMURA, M. (1967). Identification of mycobacteria. Tubercle, 48, 31 I-338.

Tsukamura, M. (1969). Numerical taxonomy of the genus Nocardia. Journal of General Microbiology 56, $265-287$. 